\title{
Novel 12-membered non-antibiotic macrolides, EM900 series with anti-inflammatory and/or immunomodulatory activity; synthesis, structure-activity relationships and in vivo study
}

\author{
Akihiro Sugawara, Akito Sueki, Tomoyasu Hirose, Hideaki Shima, Kiyoko S Akagawa, Satoshi Ōmura \\ and Toshiaki Sunazuka
}

The Journal of Antibiotics (2012) 65, 487-490; doi:10.1038/ja.2012.51; published online 4 July 2012

Keywords: anti-inflammatory and/or immunomodulatory activity; EM900; Erythromycin A; non-antibiotic macrolides

Erythromycin A (EMA), first isolated in $1952,{ }^{1}$ is a clinically useful macrolide antibiotic, active against both Gram-positive bacteria and Gram-negative cocci and mycoplasmas. In the 1980s, EMA was found to have two other promising biological properties, gastrointestinal motor-stimulating activity and anti-inflammatory and/or immunomodulatory activity by Itoh et l. $^{2}$ and Kudoh et al., ${ }^{3}$ respectively. Based on these findings, our research group has been striving to create an ideal derivative, which exhibits a specific activity without showing antibacterial effect. We have already found a new motilide derivative (EM574, de- $N$-methyl- $N$-isopropyl-8,9-anhydroerythromycin A 6,9hemiketal), which exhibited gastrointestinal motor-stimulating activity but showed no antibacterial activity. ${ }^{4-7}$

As a result of its anti-inflammatory and/or immunomodulatory activity, EMA is an effective treatment for diffuse panbronchiolitis, ${ }^{3}$ chronic sinusitis and cystic fibrosis. ${ }^{8}$ Additionally, our group reported that EMA promotes monocyte to macrophage differentiation and inhibits proliferation of $\mathrm{T}$ cell in vitro. ${ }^{9,10}$ Likewise, 14-membered macrolides are also well known to possess anti-inflammatory and/or immunomodulatory activity, which are represented by inhibition of inflammatory cytokine production. ${ }^{11-13}$ However, the detailed mode of action of EMA has not yet been determined. Macrolide derivatives with anti-inflammatory and/or immunomodulatory activity but lacking either antibacterial activity or gastrointestinal motorstimulating activity would be extremely useful, as they would help avoid promotion of drug resistance, as well as help to minimize any adverse effects of EMA treatment.

In a previous paper, ${ }^{14}$ we reported our development of the novel 12-membered (8R,9S)-8,9-dihydro-6,9-epoxy-8,9-anhydropseudoerythromycin A (EM900), and analogues thereof, possessing the ability to promote monocyte to macrophage differentiation but lacking antibacterial activity. This provided us with a novel, acid-stable 12-membered macrolide chemical skeleton with anti-inflammatory and/or immunomodulatory activity, although no detailed structureactivity relationships had been clarified. From our initial study, we learned that neither disconnection of the side chain bearing from the C11 position nor the cladinose moiety has an important role in the anti-inflammatory and/or immunomodulatory effects. Consequently, we became interested in synthesis of analogues of the $\mathrm{N}, \mathrm{N}$-dimethylamino group on desosamine moiety, inspired by our experience with erythromycin derivatives with a potent motiline-like activity, especially motilide EM574. ${ }^{4}$ Generally, the $N, N$-dimethylamino group of EMA is an essential moiety for generating antibacterial activity. In contrast, in the case of motiline-like activity, modification of the $\mathrm{N}, \mathrm{N}$-dimethylamino group dramatically increases the activity. ${ }^{4}$ Taken together, we envisioned that modification of the $N, N$-dimethylamino group might be possible as a means of increasing anti-inflammatory and/or immunomodulatory activity.

In this communication, we report the elucidation of structureactivity relationships of the $N, N$-dimethylamino group of EM900, as well as those of the analogues, $(8 R, 9 S)-\operatorname{de}\left(3^{\prime}-N\right.$-methyl $)-3^{\prime}-N-(p-$ chlorobenzyl)-8,9-dihydro-6,9-epoxy-8,9-anhydropseudoerythromycin A (EM905) and $(8 R, 9 S)-\operatorname{de}\left(3^{\prime}-N, N\right.$-dimethylamino)- $3^{\prime}$-morpholino8,9-dihydro-6,9-epoxy-8,9-anhydropseudoerythromycin A (EM914). The two compounds, EM905 and EM914, were found to be effective for treatment in a mouse model of inflammatory bowel disease (IBD), even at considerably low doses, compared with the therapeutic sulfa drug, sulfasalazine. We propose that the ability to promote monocyte to macrophage differentiation might have potential as a reliable in vitro assay system to help identify and develop potent antiinflammatory and/or immunomodulatory agents. 
At the outset, removal of a methyl group from the nitrogen of desosamine via treatment of EM900 with $\mathrm{I}_{2}$, AcONa in $\mathrm{MeOH},{ }^{15}$ provided the de- $N$-methyl analogue EM901 in 79\% yield (Table 1). Subsequent, de- $\mathrm{N}$-methylation of EM901 using $\mathrm{I}_{2}$ and $\mathrm{Na}$ in $\mathrm{MeOH}^{15}$ afforded bis-de- $\mathrm{N}$-methyl EM903 in 90\% yield. With EM901 and EM903 in hand, we synthesized 24 analogues (Appendix), such as $\mathrm{N}$-mono- and/or $\mathrm{N}, \mathrm{N}$-bis-substituted (for example, alkylated and cyclic alkylated) compounds to investigate structure-activity relationships focusing on this region. Reaction conditions (methods A-F) were as follows; (A) treatment of EM901 with alkyl halides (RI, RBr and $\mathrm{RCl}$ ), and $i-\mathrm{Pr}_{2} \mathrm{NEt}$ in $\mathrm{CHCl}_{3}$ provided $\mathrm{N}$-mono-alkylated compounds (entry 2-15); (B) treatment of EM901 or EM903 with aldehydes and $\mathrm{NaBH}(\mathrm{OAc})_{3}$ provided $\mathrm{N}$-mono or $\mathrm{N}, \mathrm{N}$-bis-alkylated compounds (entry 18, 20, 21 and 23); (C) acetylation of EM901 provided EM960 (entry 16); (D) mesylation of EM901 provided
EM961 (entry 17); (E) treatment with dibromoalkanes provided $N, N$-cyclic alkylated compounds (entry 22, 24-26); (F) removal of the $\mathrm{Cbz}$ group of EM965 was carried out under hydrogenation reaction condition to give EM966 (entry 26, step 2).

To investigate anti-inflammatory and/or immunomodulatory effects, we used the THP-1 assay system, which was modified according to the method of Keicho et al., ${ }^{10}$ to test for promotion of differentiation of monocytic cells to macrophages. A THP-1 cell line, derived from a patient with monocytic leukemia, was supplied by the Japanese Cancer Research Resources Bank (Tokyo, Japan). THP-1 cells $\left(1 \times 10^{5}\right.$ per well in $0.5 \mathrm{ml}$ ) were placed into 48 -well tissue culture microplates (IWAKI, Tokyo, Japan) and cultured in the presence of phorbol myristate acetate (PMA; $2 \mathrm{ng} \mathrm{ml}^{-1}$ ) or each macrolide compound (1-100 $\left.\mu \mathrm{M}\right)$ alone, or both, for 4 days at $37^{\circ} \mathrm{C}$ under $5 \% \mathrm{CO}_{2}$ in humidified air. The number and viability of adherent cells was measured by colorimetric

Table 1 Synthesis of $N$-substituted and $N, N$-bis-substituted analogues and their biological activities

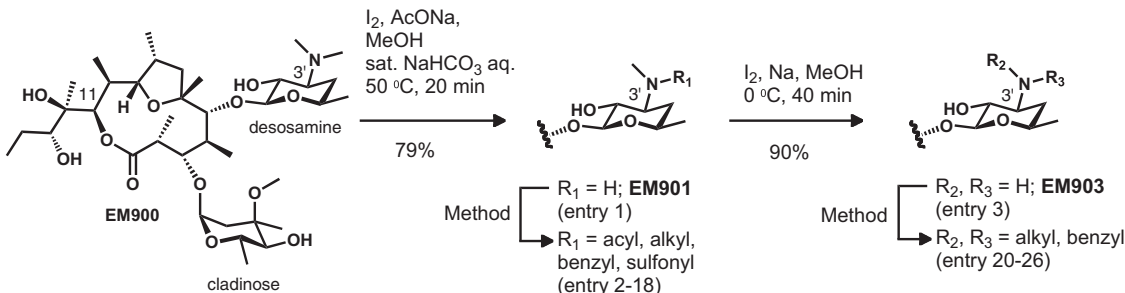

\begin{tabular}{|c|c|c|c|c|c|c|c|c|}
\hline Entry & Method & $R_{1}$ & $R_{2}$ & $R_{3}$ & Yield (\%) & Compound & $E D_{50}(\mu \mathrm{m})^{a}$ & Cytotoxicity ( $\mu \mathrm{m})$ \\
\hline- & - & - & - & - & - & EM900 & 17.1 & 100 \\
\hline \multicolumn{9}{|c|}{ N-mono alkylated analogues } \\
\hline 1 & - & $\mathrm{H}$ & - & - & 79 & EM901 & 15.9 & 100 \\
\hline 2 & A & $\mathrm{Bn}$ & - & - & 92 & EM902 & 14.5 & 100 \\
\hline 3 & A & $p-\mathrm{ClBn}$ & - & - & 93 & EM905 & 2.7 & 30 \\
\hline 4 & A & $p-\mathrm{CF}_{3} \mathrm{Bn}$ & - & - & 74 & EM919 & $>100$ & 100 \\
\hline 5 & A & $p-\mathrm{BrBn}$ & - & - & 67 & EM920 & $>100$ & 100 \\
\hline 6 & $A$ & $p-\mathrm{FBn}$ & - & - & 86 & EM921 & $>100$ & 30 \\
\hline 7 & $A$ & $o-\mathrm{ClBn}$ & - & - & 98 & EM922 & 1.2 & 100 \\
\hline 8 & A & $m-\mathrm{ClBn}$ & - & - & 86 & EM923 & 2.7 & 100 \\
\hline 9 & $A$ & $p-\mid \mathrm{Bn}$ & - & - & 90 & EM924 & $>100$ & 30 \\
\hline 10 & $A$ & propargyl & - & - & 64 & EM929 & $>100$ & $>100$ \\
\hline 11 & $A$ & Et & - & - & 86 & EM933 & $>100$ & 100 \\
\hline 12 & A & $i-\operatorname{Pr}$ & - & - & 38 & EM940 & $>100$ & 100 \\
\hline 13 & $A$ & Allyl & - & - & 54 & EM957 & $>100$ & 100 \\
\hline 14 & $A$ & $p-M e B n$ & - & - & 45 & EM958 & 4.8 & 100 \\
\hline 15 & $A$ & $p-\mathrm{MeOBn}$ & - & - & 48 & EM959 & $>100$ & 100 \\
\hline 16 & $\mathrm{C}$ & $A c$ & - & - & 100 & EM960 & $>100$ & $>100$ \\
\hline 17 & $\mathrm{D}$ & Ms & - & - & 64 & EM961 & 44.5 & $>100$ \\
\hline 18 & $B$ & Pentyl & - & - & 81 & EM962 & $>100$ & $>100$ \\
\hline \multicolumn{9}{|c|}{ N,N-Bis-alkylated analogues } \\
\hline 19 & - & - & $\mathrm{H}$ & $\mathrm{H}$ & 90 & EM903 & 27.6 & 100 \\
\hline 20 & $\mathrm{~B}$ & - & $\mathrm{Bn}$ & $\mathrm{Bn}$ & 63 & EM904 & 9.5 & 30 \\
\hline 21 & $\mathrm{~B}$ & - & $\mathrm{Bn}$ & $\mathrm{H}$ & 31 & EM912 & $>100$ & 30 \\
\hline 22 & $E$ & - & \multicolumn{2}{|c|}{$-\left(\mathrm{CH}_{2}\right)_{2} \mathrm{O}\left(\mathrm{CH}_{2}\right)_{2^{-}}$} & 89 & EM914 & 52.8 & $>100$ \\
\hline 23 & $\mathrm{~B}$ & - & $p-\mathrm{ClBn}$ & $\mathrm{H}$ & 55 & EM928 & $>100$ & 30 \\
\hline 24 & $E$ & - & \multicolumn{2}{|c|}{$-\left(\mathrm{CH}_{2}\right)_{5-}^{-}$} & 82 & EM955 & 30.3 & 100 \\
\hline 25 & $\mathrm{E}$ & - & \multicolumn{2}{|c|}{$-\left(\mathrm{CH}_{2}\right)_{4^{-}}$} & 62 & EM956 & $>100$ & 100 \\
\hline \multirow[t]{2}{*}{26} & Step 1. E & - & \multicolumn{2}{|c|}{$-\left(\mathrm{CH}_{2}\right)_{2} \mathrm{~N}(\mathrm{Cbz})\left(\mathrm{CH}_{2}\right)_{2-}$} & 61 & EM965 & $>100$ & 30 \\
\hline & Step 2. F & - & \multicolumn{2}{|c|}{$-\left(\mathrm{CH}_{2}\right)_{2} \mathrm{NH}\left(\mathrm{CH}_{2}\right)_{2^{-}}$} & 52 & EM966 & $>100$ & 100 \\
\hline
\end{tabular}

Method A: alkyl halides (for example $\mathrm{RCl}, \mathrm{RBr}, \mathrm{RI}$ ), $i-\mathrm{Pr}_{2} \mathrm{NEt}$ and $\mathrm{CHCl}_{3}$. Method $\mathrm{B}$ : aldehydes, $\mathrm{AcOH}, \mathrm{NaBH}(\mathrm{OAc})_{3}$ and 1,2-dichloroethane. Method C: $\mathrm{Ac}{ }_{2} \mathrm{O}$ and $\mathrm{DCM}$. Method $\mathrm{D}$ : $\mathrm{MsCl}$ and $\mathrm{DCM}$. Method E: dibromoalkanes, $i-\mathrm{Pr}_{2} \mathrm{NEt}$ and $\mathrm{MeCN}, 80^{\circ} \mathrm{C}$. Method $\mathrm{F}: \mathrm{H}_{2}, \mathrm{Pd}(\mathrm{OH})_{2}$ and $\mathrm{MeOH}$, room temperature, $4 \mathrm{~h}, 52 \%$.

aThe $\mathrm{ED}_{50}$ values were determined, which provided an evaluation of the promotion of monocyte to macrophage differentiation of each analogue, as compared with the result of EMA at $100 \mu \mathrm{m}$ 
determination of MTT (3-(4,5-dimethylthiazol-2-yl)-2,5-diphenyltetrazolium bromide) assay at $550 \mathrm{~nm}$. The $\mathrm{ED}_{50}$ values were determined, which provided an evaluation of the promotion of monocyte to macrophage differentiation of each analogue, as compared with the result of EMA at $100 \mu \mathrm{M}$. Cytotoxicity ( $\mu \mathrm{M})$ was determined using cell-count reagent SF (Nacalai tesque, Tokyo, Japan) according to the manufacturer's instructions.

As the bioactivity data of these analogues are summarized in Table 1, the $\mathrm{ED}_{50}$ of de- $N$-methyl and bis-de- $N$-methyl analogues EM901 and EM903 are similar compared with that of EM900 $\left(\mathrm{ED}_{50}=17.1 \mu \mathrm{M}\right)$. Of the $N$-benzyl analogues $(N$-mono-alkylated analogues), EM902 $\left(\mathrm{ED}_{50}=14.5 \mu \mathrm{M}\right)$ exhibited a similar effect to EM900 $\left(\mathrm{ED}_{50}=17.1 \mu \mathrm{M}\right)$, whereas the $p$-chlorobenzyl group (for example, EM905 $\left.\left(\mathrm{ED}_{50}=2.7 \mu \mathrm{M}\right)\right)$ is five times more potent than EM900. Interestingly, the other $p$-substituted benzyl analogues (for example, $\mathrm{CF}_{3}$ (EM919), F (EM921), I (EM924), Br (EM920) and OMe (EM959); see entry 4-6, 9 and 15) dramatically decreased the anti-inflammatory and/or immunomodulatory effects $\left(\mathrm{ED}_{50}>100\right.$ $\mu \mathrm{M}$ ) except for the $p$-methylbenzyl group (EM958, $\mathrm{ED}_{50}=4.8 \mu \mathrm{M}$ ). In addition, the $o$ - or $m$-chloro benzyl analogues, EM922 $\left(\mathrm{ED}_{50}=1.2\right.$ $\mu \mathrm{M})$ and EM923 $\left(\mathrm{ED}_{50}=2.7 \mu \mathrm{M}\right)$, also increased the anti-inflammatory and/or immunomodulatory effects as did EM905. These results suggested that the chloro group has a remarkably important role in the anti-inflammatory and/or immunomodulatory effect. The $\mathrm{N}$-alkylated analogues, such as propargyl (EM929), ethyl (EM933), $i$-propyl (EM940) and allyl (EM957) (entry 10-13, ED E0 $>100 \mu \mathrm{M}$ ), showed no effect, indicating that a benzyl moiety might be necessary to develop the anti-inflammatory and/or immunomodulatory effect. Likewise, conversion to the acetamide moiety (entry 16, EM960, $\left.\mathrm{ED}_{50}>100 \mu \mathrm{M}\right)$ completely removed any anti-inflammatory and/or immunomodulatory properties. In contrast, in terms of $\mathrm{N}, \mathrm{N}$-bisalkylated analogues, the bis-de- $N$-methyl analogue EM903 slightly decreased the anti-inflammatory and/or immunomodulatory effects $\left(\mathrm{ED}_{50}=27.6 \mu \mathrm{M}\right)$. Conversely, the $N, N$-dibenzyl analogue (EM904) slightly increased anti-inflammatory and/or immunomodulatory effects, with cytotoxicity at $30 \mu \mathrm{m}$ in THP-1 cells. Interestingly, $\mathrm{N}$-mono-benzyl (EM912) without $\mathrm{N}$-methyl group showed no activity $\left(\mathrm{ED}_{50}>100 \mu \mathrm{M}\right.$, cf. entry 2$)$. Likewise, the $p$-chlorobenzyl group without the $N$-methyl group, EM928 $\left(\mathrm{ED}_{50}>100 \mu \mathrm{M}\right)$, completely lost anti-inflammatory and/or immunomodulatory effects. These findings suggested that the $\mathrm{N}$-methyl group has an important part in creating the anti-inflammatory and/or immunomodulatory effect. Morpholine (EM914) and piperidine (EM955) analogues expressed moderate antiinflammatory and/or immunomodulatory effects $\left(\mathrm{ED}_{50}=52.8 \mu \mathrm{M}\right.$ for EM914 (Appendix) and $30.3 \mu \mathrm{M}$ for EM955), whereas, the other three types of cyclic analogues, such as EM956, EM965 and EM966, completely lost the activity $\left(\mathrm{ED}_{50}>100 \mu \mathrm{M}\right)$.

To demonstrate the anti-inflamamatory and/or immunomodulatory effects in vivo in a rat model of IBD and to confirm that our in vitro assay system is efficient and reliable for investigating antiinflammatory agents, we selected two types of analogue, EM905 and EM914, as model compounds. IBD is a chronic inflammatory disease, as are ulcerative colitis and Crohn's disease. Treatment of IBD requires anti-inflammatory drugs and steroids, yet few anti-inflammatory agents are suitable for IBD therapy. Thus, there is a pressing need for new drugs to treat these anti-inflammatory diseases, especially compounds that possess a new skeleton and/or a new mode of action.

Crohn's disease (Sprague-Dawley) rats (Charles River Laboratories, Japan) were fasted for $24 \mathrm{~h}$ with access to water ad libitum. On day 0 , each rat was sedated by intraperitoneal injection of sodium pentobarbital $\left(50 \mathrm{mg} \mathrm{kg}^{-1}\right)$. Subsequently, $3.125 \mathrm{ml} \mathrm{kg}^{-1}$ of 2,4,6-trinitrobenzene sulfonic acid (Wako Pure Chemical Industries, Tokyo, Japan), $33.3 \mathrm{mg} \mathrm{ml}^{-1}$ in $33 \%$ ethanol/saline, was infused using a polyethylene tube, inserted through the rectum into the colon to a distance of $8 \mathrm{~cm}$. The 2,4,6-trinitrobenzene sulfonic acid was retained in the colon for $60 \mathrm{~min}$, after which the fluid was withdrawn. On day 2 , we confirmed whether a colonic lesion had been generated in each rat by fecal occult blood test, and colitis-induced rats were divided into five groups for treatment as follows: group 1: $10 \mathrm{mg} \mathrm{kg}^{-1}$ EM905 treatment $(n=14)$; group 2: $30 \mathrm{mg} \mathrm{kg}^{-1}$ EM905 treatment $(n=15)$; group 3: $10 \mathrm{mg} \mathrm{kg}^{-1}$ EM914 treatment $(n=15)$; group 4: $30 \mathrm{mg} \mathrm{kg}^{-1}$ EM914 treatment $(n=13)$; and vehicle control $(n=15)$. Test compounds were prepared by suspending in $0.5 \%$ sodium carboxymethyl cellulose (CMC-Na, Wako Pure Chemical Industries) at 2 or $6 \mathrm{mg} \mathrm{ml}^{-1}$ and orally administered twice daily by force with a microtube from day 2 to 7 . On day 8, rats were killed, the colon was excised and opened longitudinally, rinsed with cold saline and colonic damage was evaluated according to a scale ranging $0-10 .{ }^{16}$ (Scale ranging: 0, normal appearance; 1, focal hyperhemia and slight thickening (no ulcers); 2, hyperhemia and prominent thickening (no ulcers); 3, ulceration with inflammation at one site; 4 , ulceration with inflammation at two or more sites; 5, tissue damage extending $>1 \mathrm{~cm}$ length; $6-10$, area of tissue damage extending $>2 \mathrm{~cm}$ length, the score being increased by 1 for each additional $\mathrm{cm}$ of involvement).

The data indicated the impact on experimental colitis, 2,4, 6-trinitrobenzene sulfonic acid treatment inducing severe macroscopic inflammation in the colon after rectal administration, as assessed by the colonic damage score $(4.27 \pm 0.38)$, that is, hyperemia,

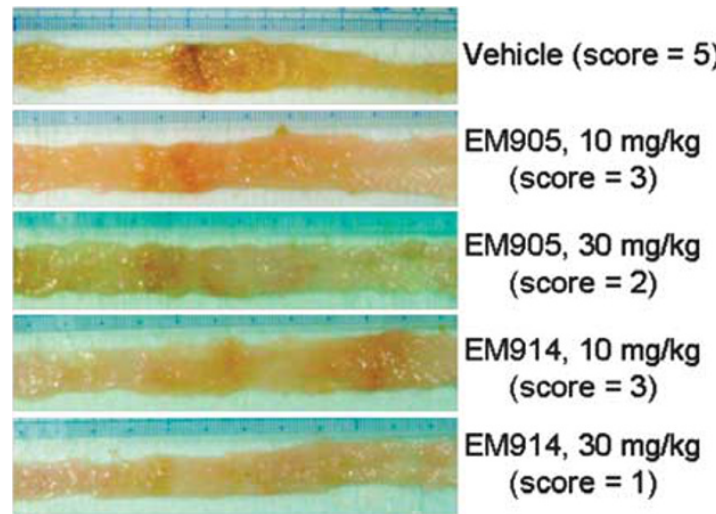

\begin{tabular}{|c|c|c|c|}
\hline \multirow{2}{*}{ Compound } & Dose & \multirow{2}{*}{$\mathrm{N}$} & \multirow{2}{*}{$\begin{array}{l}\text { Inflammatory score in } \\
\text { the intestinum crassum }\end{array}$} \\
\hline & $\mathrm{mg} / \mathrm{kg} /$ day & & \\
\hline Control (0.5\%CMC-Na) & - & 15 & $4.27 \pm 0.38$ \\
\hline \multirow[t]{2}{*}{ EM905 } & $10 \times 2$ & 14 & $3.29 \pm 0.22$ \\
\hline & $30 \times 2$ & 15 & $2.67 \pm 0.40^{*}$ \\
\hline \multirow[t]{2}{*}{ EM914 } & $10 \times 2$ & 15 & $2.93 \pm 0.41$ \\
\hline & $30 \times 2$ & 13 & $2.69 \pm 0.33^{\star}$ \\
\hline sulfasalazine & $300 \times 2$ & 12 & $2.70 \pm 0.40^{\star}$ \\
\hline Prednisolone & $3 \times 2$ & 12 & $2.30 \pm 0.40^{\star *}$ \\
\hline
\end{tabular}

Figure 1 Effect of EM905 and EM914 with 6 days repeated oral administration on 2,4,6-trinitrobenzene sulfonic acid-induced colitis. Score means the following grade of colitis: 0 , normal appearance; 1 , focal hyperhemia and slight thickening; 2, hyperhemia and prominent thickening, no ulcers; 3 , ulceration with inflammation at one site; 4, ulceration with inflammation at two or more site; 5 , tissue damage extending $>1 \mathrm{~cm}$ length; $6-10$, area of damage extending $>2 \mathrm{~cm}$ length, the score being increased by 1 for each additional $\mathrm{cm}$ of involvement. Test solutions were administered orally at the volume of $5 \mathrm{ml} \mathrm{kg}^{-1}$ for 6 days. $N=$ number, ${ }^{*} P<0.05$ and ${ }^{*} P<0.01$. 
thickening of the bowel and the extent of ulceration. Treatment with EM905 and EM914 reduced the severity of the gross lesion score in a dose-dependent manner as shown in Figure 1. Both EM905 and EM914 at lower dose $\left(10 \mathrm{mg} \mathrm{kg}^{-1}\right)$ had little effect (EM905: $3.29 \pm 0.22$ and EM914: $2.93 \pm 0.41)$ without statistical significance, whereas the higher dosage $\left(30 \mathrm{mg} \mathrm{kg}^{-1}\right)$ had a significant effect on the intensity of the inflammatory response (EM905: $2.67 \pm 0.40$ and EM914: $2.69 \pm 0.33$ ). The effect was approximately equal for the two compounds. Considering their biological and chemical properties, EM905 showed greater promotion of monocyte differentiation than EM914 (Table 1). However, EM905 is considerably more hydrophobic than EM914, so it was assumed that the bioavailability of EM905 was much lower than EM914 when administered orally to the rats.

In conclusion, we have developed two analogues, EM905 and EM914, which exhibit similar beneficial impact on treatment of IBD in rats, dramatically decreasing dosages required when compared with therapeutic sulfa drugs such as sulfasalazine. The results suggested that the promotion of monocyte to macrophage differentiation may be a reliable and accurate assay to allow in vitro evaluation of potential and promising anti-inflammatory agents. The mode of action of these compounds is not yet fully elucidated and investigation of the EM900-binding protein is underway in our laboratory.

\section{ACKNOWLEDGEMENTS}

This work was supported by a Grant for the 21st Century COE Program, and a Grant-in-Aid for Scientific Research on Innovative Areas 'Chemical Biology of Natural Products' from The Ministry of Education, Culture, Sports, Science and Technology, Japan. We thank Ms Chikako Sakabe, Ms Akiko Nakagawa and Ms Noriko Sato for various instrumental analyses.
1 McGuire, J. M. et al. Ilotycin, a new antibiotic. Antibiot. Chemother. 2, 281-283 (1952)

2 Itoh, Z., Nakaya, M., Suzuki, H., Arai, H. \& Wakabayashi, K. Erythromycin mimics exogenous motilin in gastrointestinal contractile activity in the dog. Am. J. Physiol. 247, G688-G694 (1984).

3 Kudoh, S. et al. Clinical effect of low-dose long-term erythromycin chemotherapy on diffuse panbronchiolitis. Jap. J. Thorac. Dis. 25, 632-642 (1987) (in Japanese with English abstract).

4 Ōmura, S. et al. Gastrointestinal motor-stimulating activity of macrolide antibiotics and the structure-activity relationship. J. Antibiot. 38, 1631-1632 (1985).

5 Ōmura, S. et al. Macrolides with gastrointestinal motor stimulating activity. J. Med. Chem. 30, 1941-1943 (1987).

6 Tsuzuki, K. et al. Motilides, macrolides with gastrointestinal motor stimulating activity I. $\mathrm{O}$-Substituted and tertiary $\mathrm{N}$-substituted derivatives of 8,9-anhydroerythromycin A 6,9-hemiacetal. Chem. Pharm. Bull 37, 2687-2700 (1989).

7 Sunazuka, T. et al. Motilides, macrolides with gastrointestinal motor stimulating activity. II. Quaternary $N$-substituted derivatives of 8,9-anhydroerythromycin A 6,9hemiacetal and 9, 9-dihydroerythromycin A 6, 9-epoxide. Chem. Pharm. Bull. 37, 2701-2709 (1989)

8 Gaylor, A. S. \& Reilly, J. C. Therapy with macrolides in patients with cystic fibrosis Pharmacotherapy 22, 227-239 (2002).

9 Keicho, N., Kudoh, S., Yotsumoto, H. \& Akagawa, K. S. Antilymphocytic activity of erythromycin distinct from that of FK506 or cyclosporine A. J. Antibiot. 46, 1406 1413 (1993).

10 Keicho, N., Kudoh, S., Yotsumoto, H. \& Akagawa, K. S. Erythromycin promotes monocyte to macrophage differentiation. J. Antibiot. 47, 80-89 (1994).

11 Ōmura, S. (ed.). in Macrolide Antibiotics. Chemistry, Biology, and Practice. 2nd edn Ch. 12 (Academic press, Boston, 2002).

12 Labro, M. T. Immunological effects of macrolides. Curr. Opin. Infect. Dis. 11, 681-688 (1998)

13 Culic, O., Erakovic, V. \& Parnham, M. J. Anti-inflammatory effects of macrolide antibiotics. Eur. J. Pharmacol. 429, 209-229 (2001).

14 Sugawara, A. et al. Novel 12-membered non-antibiotic macrolides from erythromycin A; EM900 series as novel leads for anti-inflammatory and/or immunomodulatory agents. Bioorg. Med. Chem. Lett. 21, 3373-3376 (2011).

15 Freiberg, L. A. De-N-methyl-N-substitued erythromycin derivatives. US 3681325 (1972).

16 Wallace, J. L., MacNaughton, W. K., Morris, G. P. \& Beck, P. L. Inhibition of leukotriene synthesis markedly accelerates healing in a rat model of inflammatory bowel disease. Gastroenterology 96, 29-36 (1989).

\section{APPENDIX}

Experimental procedure and physico-chemical properties of EM914 To a solution of EM903 $(24.2 \mathrm{mg}, 0.035 \mathrm{mmol})$ in $\mathrm{CH}_{3} \mathrm{CN}(7.0 \mathrm{ml})$ was added with $i$ - $\mathrm{Pr}_{2} \mathrm{NEt}(61.0 \mu \mathrm{l}, 0.350 \mathrm{mmol})$ and bis(2-bromoethyl)ether $(44.0 \mu \mathrm{l}, 0.350 \mathrm{mmol})$ at room temperature. The reaction was allowed to warm to $80^{\circ} \mathrm{C}$ and then stirred at $80^{\circ} \mathrm{C}$ for $20 \mathrm{~h}$. After cooling to room temperature, $i-\operatorname{Pr}_{2} \mathrm{NEt}(61.0 \mu \mathrm{l}$, $0.350 \mathrm{mmol})$ and bis(2-bromoethyl)ether $(44.0 \mu \mathrm{l}, 0.350 \mathrm{mmol})$ were further added to the reaction. The reaction was allowed to warm to $80^{\circ} \mathrm{C}$ and then stirred at $80^{\circ} \mathrm{C}$ for $6 \mathrm{~h}$. The reaction was quenched with saturated aqueous $\mathrm{Na}_{2} \mathrm{~S}_{2} \mathrm{O}_{3}(7 \mathrm{ml})$ and extracted with $\mathrm{CHCl}_{3}$ $(10 \mathrm{ml}, \times 1)$. The organic layer was washed with saturated aqueous $\mathrm{Na}_{2} \mathrm{~S}_{2} \mathrm{O}_{3}(7 \mathrm{ml}, \times 1)$, saturated aqueous $\mathrm{NH}_{4} \mathrm{Cl}(7 \mathrm{ml}, \times 1)$ and brine $(7 \mathrm{ml}, \times 1)$, dried over $\mathrm{Na}_{2} \mathrm{SO}_{4}$, filtered and concentrated in vacuo. The crude product was purified by silica gel flash column chromatography $\left(\mathrm{CHCl}_{3} / \mathrm{MeOH} / \mathrm{NH}_{4} \mathrm{OH}=100 / 1 / 0.1-30 / 1 / 0.1\right)$ to afford EM914 $(23.6 \mathrm{mg}, 89 \%)$ as a pale yellow solid.

EM914 $\left.[\alpha]_{\mathrm{D}}^{24}-27.6(c) 1.0, \mathrm{CHCl}_{3}\right), \mathrm{mp}=130.5-135.9^{\circ} \mathrm{C}, \quad \mathrm{IR}$ $(\mathrm{KBr}) v_{\mathrm{cm}}^{-1} ; 3465,2969,2938,2881,1708,1635,1457,1378$,
1268, 1164, 1112, 1054 and 1018. ${ }^{1} \mathrm{H}$ NMR $\left(500 \mathrm{MHz}, \mathrm{CDCl}_{3}\right) \delta$ (p.p.m.): 5.50 (s, $1 \mathrm{H}), 4.78$ (d, $J=4.0 \mathrm{~Hz}, 1 \mathrm{H}), 4.33(\mathrm{~d}, J=6.9 \mathrm{~Hz}$, $1 \mathrm{H}), 4.24(\mathrm{~d}, J=10.3 \mathrm{~Hz}, 1 \mathrm{H}), 3.99(\mathrm{dq}, J=9.2,6.3 \mathrm{~Hz}, 1 \mathrm{H}), 3.89$ $(\mathrm{d}, J=9.2 \mathrm{~Hz}, 1 \mathrm{H}), 3.77-3.65$ (complex m, $5 \mathrm{H}), 3.47(\mathrm{~m}, 1 \mathrm{H}), 3.24$ $(\mathrm{s}, 3 \mathrm{H}), 3.24-3.21(\mathrm{~m}, 1 \mathrm{H}), 2.99(\mathrm{t}, J=9.8 \mathrm{~Hz}, 1 \mathrm{H}), 2.80(\mathrm{dd}$, $J=9.8, \quad 5.2 \mathrm{~Hz}, \quad 1 \mathrm{H}$ ), 2.72-2.52 (complex m, 5H), 2.41-2.32 (complex m, 3 H), $2.14(\mathrm{~m}, 1 \mathrm{H}), 2.04(\mathrm{~m}, 1 \mathrm{H}), 1.86(\mathrm{dd}, J=12.3$, $3.4 \mathrm{~Hz}, 1 \mathrm{H}), 1.75(\mathrm{bd}, J=11.5 \mathrm{~Hz}, 1 \mathrm{H}), 1.65(\mathrm{~m}, 1 \mathrm{H}), 1.52(\mathrm{dd}$, $J=15.2,4.3 \mathrm{~Hz}, 1 \mathrm{H}), 1.37(\mathrm{~m}, 1 \mathrm{H}), 1.34-1.33$ (complex m, $4 \mathrm{H})$, $1.33(\mathrm{~s}, 3 \mathrm{H}), 1.29(\mathrm{~d}, J=7.0 \mathrm{~Hz}, 3 \mathrm{H}), 1.22-1.19$ (complex m, $7 \mathrm{H})$, $1.21(\mathrm{~s}, 3 \mathrm{H}), 1.11(\mathrm{~s}, 3 \mathrm{H}), 1.11-1.10$ (complex m, $3 \mathrm{H}), 1.08$ $(\mathrm{d}, J=7.5 \mathrm{~Hz}, 3 \mathrm{H}), 0.96(\mathrm{~d}, J=7.2 \mathrm{~Hz}, 3 \mathrm{H})$, internal solvent peak $\left(\mathrm{CDCl}_{3} 7.26\right.$ p.p.m.), ${ }^{13} \mathrm{C} \mathrm{NMR}\left(125 \mathrm{~Hz}, \mathrm{CDCl}_{3}\right) \delta$ (p.p.m.): 177.2, 103.8, 98.1, 84.0, 83.2, 82.7, 80.6, 78.0 (2C), 75.9, 74.8, 72.4, 70.0, 69.0, 67.0 (2C), 66.0, 65.4, 49.2, 48.8 (2C), 46.6, 41.7, 36.5, 35.1, $33.8,33.5,30.3,22.5,22.2,21.4,21.0,18.0,17.5,16.9,16.0,13.9$, 12.0 , 9.5, internal solvent peak $\left(\mathrm{CDCl}_{3} 77.00\right.$ p.p.m.), HRMS FAB (PEG600+ NaI) $\mathrm{mz}^{-1}: 760.4885[\mathrm{M}+\mathrm{H}]^{+}$, calcd for $\mathrm{C}_{39} \mathrm{H}_{70} \mathrm{NO}_{13}$ : 760.4847 . 